\title{
The Effectiveness of Study Program Quality Improvement (A Case Study at Islamic Education Management Department, Faculty of Tarbiyah and Teacher Training)
}

\author{
Badrudin \\ badrudin73@yahoo.com
}

\begin{abstract}
The effectiveness of a study program's quality improvement is its strength, capacity, and habit in implementing the functions of department management in order to gain the expected quality. The lack of efforts in the improvement of the quality caused by management is not functioned properly in line with the context of Islamic Education Management Department. The aims of this study were describing and analysing: (1) vision, missions, objectives, and indicators of a qualified study program; (2) Supported policies to improve; (3) the strategy in achieving quality; (4) capacity building; (5) quality leadership; and (6) the future perspective for quality. The design of this study was descriptive research with qualitative approach. The data were analysed using descriptive analysis, which consists; data collection, data display, data reduction, and conclusion drawing/verification. The findings showed that visions, missions, objectives, and indicators are carried good academic quality and moral. Regulation had implemented which is applying of Quality assurance (ISO 9001: 2008), empowering human resources, and integration of Information and Communication Technology (ICT).
\end{abstract}

Keywords-Effectiveness, Quality Management, Study Program

\section{INTRODUCTION}

All parties and stakeholders expect that the quality of education can be measured when it has met the established quality standard requirement. The establishment of that standard should refer to the guidelines from the Board of National Education Standards for the effective implementation and management of the national education. The arrangement of this national standard is based on Government Regulation No. 19 Year 2005 on National Education Standards [10]. In Article 1, paragraph (1) of Government Regulation 19 Year 2005, it is stated "National educational standards mean the minimal criteria about education system in the whole jurisdiction of the Republic of Indonesia". National educational standards entail standards of content, process, graduate competencies, educators and education personnel, facilities and infrastructures, management, financing, and assessment. Higher education institutions also have their own national standards. These cover the eight national educational standards and the national standard of research and community services (Regulation of the Minister of
Education and Culture of the Republic of Indonesia Number 49 Year 2014 Article 1, Paragraph 1).

This research focuses on conducting an empirical analysis of the implemented strategies for the quality improvement of the study program (a case study at Undergraduate study program of Islamic Education Management). Islamic Education Management Department, Faculty of Tarbiyah and Teacher Education UIN SGD Bandung has a vision to be an advanced and competitive department in the field of Islamic education management in Indonesia toward ISO 2015 certification.

In fact, there is a gap between the ideal implementation of quality improvement and the actual implementation. While the ideal implementation requires a continuous enhancement, the real execution does not do it constantly. Moreover, when the expected quality is not well achieved, there is no straight refinement for it is only held once in a semester. The quality implementation strategy also puts too much attention to inputs such as lecturer training as well as sophistication and refinement of facilities and infrastructures. The stakeholders believe that when these inputs are fine, the quality of the education will axiomatically improve. In point of fact, the expected quality is not entirely achieved since the focus is given to the inputs instead of the educational process. Another problem identified in this study is the lack of parents' and community's roles in the process of education. Their major contribution is merely in the form of financial support rather than the educational process, particularly its monitoring and evaluation.

The aims of this study were describing and analysing: (1) vision, missions, objectives, and indicators of a qualified study program; (2) Supported policies to improve; (3) the strategy in achieving quality; (4) capacity building; (5) quality leadership; and (6) the future perspective for quality.

\section{LITERATURE REVIEW}

Generally, the theory of effectiveness orientates itself more toward the goals. Effectiveness emphasizes on the suitability of the results achieved by a certain organization with its goals [15]. An organization's effectiveness shows suitability between what it achieves and 
what it aims to achieve [13]. Thus, an organization's effectiveness means its potential to attain multiple purposes and its ability to adapt with its surroundings.

Role of educational institutions need to insist on the concept of service quality management and implementation of the program through improved management performance [7]. Innovation does not become an important meaning when no significant effect on performance because of the leadership [3]. Liveliness personal relationships and performance are complex and even the power of leadership is to give suggestions on the outstanding performance of the workers [5]. Through the efforts of build quality and service quality of institutions at any level, which are sustainable development program with the various aspects that influence it is necessary for the quality of service provided by an institution [2].

Table bellow shows effective institution possesses the following criteria [12].

Table 1: The Criteria of an Effective Institution

\begin{tabular}{|c|c|c|}
\hline $\begin{array}{l}\text { Smith and } \\
\text { Purkey }\end{array}$ & $\begin{array}{l}\text { Scheerens and } \\
\text { Bosker }\end{array}$ & Satori and Komariah \\
\hline $\begin{array}{l}\text { 1. Instructional } \\
\text { leadership }\end{array}$ & $\begin{array}{l}\text { 1. Educational } \\
\text { leadership }\end{array}$ & 1. Authentic leadership \\
\hline $\begin{array}{l}\text { 2. Planned and } \\
\text { purposeful } \\
\text { curriculum }\end{array}$ & $\begin{array}{l}\text { 2. Curriculum } \\
\text { quality/opportunity } \\
\text { to learn }\end{array}$ & $\begin{array}{l}\text { 2. Scientific and practical } \\
\text { curriculum }\end{array}$ \\
\hline $\begin{array}{l}\text { 3. Clear goals and } \\
\text { high } \\
\text { expectations }\end{array}$ & $\begin{array}{l}\text { 3. Achievement } \\
\text { orientation }\end{array}$ & $\begin{array}{l}\text { 3. Excel both in academic } \\
\text { and non-academic } \\
\text { achievements }\end{array}$ \\
\hline 4. Time on task & $\begin{array}{l}\text { 4. Effective learning } \\
\text { time }\end{array}$ & $\begin{array}{l}\text { 4. Active, innovative, } \\
\text { creative, effective, and } \\
\text { fun learning }\end{array}$ \\
\hline $\begin{array}{l}\text { 5. Recognition of } \\
\text { academic } \\
\text { success }\end{array}$ & $\begin{array}{l}\text { 5. Feedback and } \\
\text { reinforcement }\end{array}$ & $\begin{array}{l}\text { 5. Consistent recognitions } \\
\text { of achievements }\end{array}$ \\
\hline 6. Orderly climate & 6. Classroom climate & $\begin{array}{l}\text { 6. OCB (organization } \\
\text { Citizenship Behaviour) } \\
\text { school of civil society }\end{array}$ \\
\hline $\begin{array}{l}\text { 7. Sense of } \\
\text { community }\end{array}$ & 7. School climate & $\begin{array}{l}\text { 7. Group learning } \\
\text { behaviour and self } \\
\text { assessment }\end{array}$ \\
\hline $\begin{array}{ll}\text { 8. } & \text { Parental } \\
\text { support and } \\
\text { involvement }\end{array}$ & $\begin{array}{ll}\text { 8. } & \text { Parental } \\
\text { involvement }\end{array}$ & $\begin{array}{l}\text { 8. Parents' awareness and } \\
\text { active participation }\end{array}$ \\
\hline $\begin{array}{l}\text { 9. School site } \\
\text { management }\end{array}$ & $\begin{array}{l}\text { 9. Independent } \\
\text { learning }\end{array}$ & $\begin{array}{l}\text { 9. Green and clean } \\
\text { learning environment }\end{array}$ \\
\hline $\begin{array}{ll}10 . & \begin{array}{l}\text { Staff } \\
\text { development }\end{array} \\
\end{array}$ & $\begin{array}{ll}\text { 10. } & \begin{array}{l}\text { Evaluative } \\
\text { potential }\end{array} \\
\end{array}$ & 10. $\begin{array}{l}\text { Sustainable action } \\
\text { plan }\end{array}$ \\
\hline 11. Staff ability & $\begin{array}{l}\text { 11. Consensus and } \\
\text { cohesion }\end{array}$ & $\begin{array}{ll}11 . & \text { Consensus on } \\
\text { Continuing } \\
\text { Professional } \\
\text { Development (CPD) }\end{array}$ \\
\hline $\begin{array}{l}\text { 12. Collegial } \\
\text { and } \\
\text { collaborative } \\
\text { planning }\end{array}$ & $\begin{array}{l}\text { 12. Structured } \\
\text { instruction }\end{array}$ & $\begin{array}{ll}12 . & \text { Merit-Based } \\
& \text { Incentive Payment } \\
& \text { System (MIPS) }\end{array}$ \\
\hline $\begin{array}{ll}\text { 13. } & \text { Direct } \\
\text { support }\end{array}$ & & $\begin{array}{ll}\text { 13. } & \text { Learning } \\
\text { Organization model } \\
\text { 4cees }\end{array}$ \\
\hline
\end{tabular}

\section{RESEARCH METHOD}

This study applied descriptive method with qualitative approach because it aims to get a comprehensible illustration from the data about the effectiveness of quality improvement strategies at the Undergraduate study program of Islamic Educational Management, Faculty of Tarbiyah and Teacher Training UIN Sunan Gunung Djati Bandung.

Table 2: The Units of Analysis and the Research Subjects

\begin{tabular}{|c|l|ll|c|}
\hline No & Units of Analysis & \multicolumn{1}{|c|}{ Research Subjects } & Code \\
\hline 1 & $\begin{array}{l}\text { Undergraduate } \\
\text { study program of } \\
\text { Islamic Educational } \\
\begin{array}{l}\text { Management (IEM), } \\
\text { Faculty of Tarbiyah } \\
\text { and Teacher }\end{array}\end{array}$ & $\begin{array}{l}\text { 2. } \\
\text { Training }\end{array}$ & $\begin{array}{l}\text { Dean of the Faculty } \\
\text { Vice Dean of the Faculty } \\
\text { Secretary of the Department } \\
\text { (IEM) }\end{array}$ & $\begin{array}{c}\text { D } \\
\text { Staffs of the Department } \\
\text { (IEM) } \\
\text { SJ }\end{array}$ \\
Students & S \\
\hline
\end{tabular}

The data gathered in this study were in the forms of schema, narration, and description. The information from the respondents, either written or oral information, as well as their behaviours became the sources of the data. To collect the data, the researcher conducted a field observation to get a field note as the qualitative data source. The data analysis technique is presented as follows.

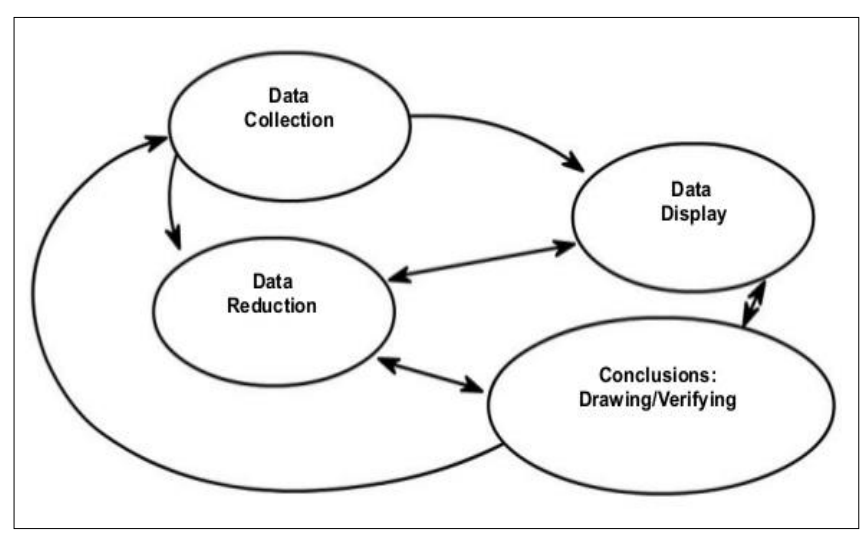

Figure 1. Components of qualitative data analysis (Interactive Model of Miles \& Huberman, 1984: 20)

\section{FINDINGS AND DISCUSSIONS}

\section{Research Findings}

This part contains the description of the research findings, which are divided into six segments as previously mentioned in the aims of this study. These are: (1) Visions, missions, objectives, and indicators of a qualified study program; (2) Quality strategy policies; (3) Quality improvement strategy; (4) Capacity building; (5) Quality leadership; and (6) Quality improvement perspectives. 
1. Visions, Missions, Objectives, and Indicators of a Qualified Study Program

The vision of Islamic Educational Management Study Program is "Becoming an advanced, competitive, and professional department in the field of Islamic educational management in Indonesia toward ISO 2015 Certification".

This vision is then translated into four broader missions as follows:

a. Conducting educational teaching and training on Islamic educational management based on research-based learning model in order to develop the quality assurance and to achieve the total quality management in education.

b. Conduct research for scientific and innovative work developments, which are relevant to education management discipline.

c. Actualize the commitment to performance and academic quality among the academicians in Islamic Educational Management study program

d. Conduct partnerships and community services with various government agencies and societies both national and international.

\section{Quality Strategy Policies}

There is four-quality strategy policies applied in this study programs. There are:

a. Establish Quality Management System (QMS) ISO 9001: 2008 as the basis of as the basis of its continuous improvement of the education quality in every single activity.

b. Improve the deployment of the existing human resources as well as facilities and infrastructures.

c. Excel the competencies of the educators and the education personnel.

d. Maximize the utilization of Information and Communication Technology (ICT) to support the learning process and services for the students.

\section{Quality Improvement Strategy}

The strategy for achieving the intended program was by refining the teaching and learning strategies as well as developing the Strategic Plan (Renstra) and Annual Performance Plan (RKT).

\section{Capacity Building}

Those who count as the human resources of Islamic Education Management study programs are the lecturers and education personnel or staffs. Some programs were held to develop the competencies of the human resources at the Undergraduate study program of Islamic Educational Management, Faculty of Tarbiyah and Teacher Training UIN Sunan Gunung Djati Bandung. These programs were: creating team teaching; conducting ICT trainings for lecturers and staffs; joining leadership quality management trainings, especially the head of the department; registering the head of the department in the trainings of supervision, monitoring and evaluation, department administration and evaluation; increasing the English communication competence of the lecturers and the education personnel; raising the number of the lecturers to join educator certification; and enquiring the education personnel to attend related training for their self-development.

\section{Quality Leadership}

The criteria of a good leader of a department/ study program is not only assessed from his/her consistency in running the department's rules and management, but also his/her direct contribution in supervision. The supervisions done by the head of the department were aimed at ensuring the efficiency of class hours and the autonomy of the lecturers in teaching. The head of the department used a scoring rubric as the instrument to assess the lecturers' performances in the classrooms by observing the classes without interrupting. As the follow-up action, the head of the department carried out a professional dialogue with the lecturers to discuss the problems he/she found during the classroom supervision. This dialogue should have positive impact and should encourage the lecturers to find innovative solutions to the problems.

\section{Quality Improvement Perspectives}

Islamic Education Management Department created the standards for each aspect stated in the National Standard of Higher Education. After that, the final stages of quality improvement were supervision, monitoring, and evaluation. These actions facilitated the leader to be able to assess the effectiveness of the program, the obstacles that might occur, and the solution to these obstacles. The supervision, monitoring, and evaluation were conducted by the head of the department and the team and these covered the activities related to the fulfilment of the department's supervision, the department monitoring fulfilment, the department implementation, the department's performance evaluation program fulfilment, and the lecturers' and the education personnel's performance evaluation program fulfilment.

\section{Discussions}

\section{Visions, Missions, Objectives, and Indicators of a Qualified Study Program}

Islamic Education Management Department Study Program pointed out the achievement of the criteria of an international standard study program based on ISO 9001: 2008. Thus, the mission was now slightly changed into a study program, which emphasized the students' noble characters. The department's objectives were highlighted in the administrative requirements of teaching and learning of international standard according to ISO 9001: 2008 as the main goal. The quality was anchored to the National Standard of Higher Education and was accentuated on the lecturers' and the staffs' professional development. The missions of the department were rooted from the brand characters of the department with Islamic education management value reinforcement. 


\section{Quality Strategy Policies}

The quality strategy policies, which were implemented in Islamic Education Management Department, would determine the quality of the department. There should be a commitment to the policies related to: the quality, the quality enhancement, and the sources of the quality, management roles, qualified implementation, and satisfying public services.

\section{Quality Improvement Strategy}

The action plans taken by Islamic Education Management Department in order to enhance the eminence of the teaching and learning were usually conducted at the beginning of each semester in the forms of syllabus and course description and course content. Additionally, the lecturers also formulated the indicators to assess the students' attitude and performance in college.

The next stage after the preparation stage mentioned above is the implementation step. During the implementation stage (teaching-learning process), supervision, monitoring and evaluation were conducted to assess the lecturers' performances, with indicators that had been formulated by the supervision team.

Effective implementation of the action plan of the Departments' activities will give opportunity to enhance education quality [6]. To understanding quality that emphasises learning for social development, through the promotion of Life Skills. However, despite setting goals of quality education in terms that embrace a broad range of personal and social learning outcomes, assessment of progress in achieving quality is mainly restricted to those cognitive learning outcomes that are easy to measure using pen and paper tests [1].

Quality improvement can be possibly gained if the study program is facilitated with sufficient quality management implementation. Moreover, it should be kept in mind that the term 'quality management' has a range of definitions, which all are related to the aspect of assessment, design, implementation, evaluation, and a continuum effort to improve the quality of the institution.

\section{Capacity Building}

Educational quality of education can be gained implementing quality assurance. It becomes imperative for the development and principles for development scenario considering the quality of higher education quality assurance will involve the two sides of the quality that should be accounted for the quality of teaching itself in the form of quality teaching and learning process in the form of input or students [17].

In order to excel the professional competencies of the lecturers and the education personnel, Islamic Education Management Study Program facilitated them to join relevant trainings and workshops so that they could directly practice the new insight and knowledge in their work field, either in their classrooms or at the office. For the education personnel, they were also required to complete their administrative requirements, to stick of the rules, and to accomplish their responsibilities effectively. All these activities aimed at improving the quality of these parties' performances, which further would also give impact on the effectiveness of the department's programs. Such activities are also mentioned by the World Bank [14] that capacity building for the sake of human resource development could be gained through trainings as a motivational process for educators and education personnel.

\section{Quality Leadership}

The quality concepts related to improving the quality of higher education output, including the quality of staff members, course contents, students, and facilities. Also, the research also explains the different types of models in electronically higher education. This means that there is a significant relationship between the quality of staff members, course content, students and facilities and higher educational output at education systems [4].

Based on the observation and interview results, inviting the head of the department as the respondent, he had a further vision, or so-called 'dream' to gain the objectives that had been targeted by the department. In addition, the head of the department also openly communicated this vision with the department's stakeholders, lecturers and all related parties so that a positive and intense discussion could be created. J.V. Quigley argues that the power of a leader can be seen from his/her capacity to translate his/her vision and values into real implementation.

\section{Quality Improvement Perspectives}

The dream of the department was becoming a department with international standard based on ISO 9001: 2008. Reviewed from its human resources' performance, there would be several actions for their quality improvements. The standard of process would be developed, particularly the use if ICT for learning would be pointed out as the basis of learning process improvement. The standard of facilities and infrastructures would be added and refined to ease to works within the department. The standard of assessment would also be reconsidered in order to gain the expected continuum assessment quality.

Islamic Education Management Department focused on its education quality, access and equalization, educational efficiency, education relevancy, graduate competitiveness, and public acknowledgement. This department also emphasized the fulfilment of the National Standard of Higher Education. To be able to actualize these targets, Islamic Education Management Department put future the attention to the improvement of its facilities and infrastructures, the students' learning quality, and the lecturers as well as the education personnel's professional quality.

\section{CONCLUSIONS AND SUGGESTIONS}

This study concludes that the effectiveness of improvement's department in higher education can be 
gained clearly of vision-mission, empowering human resources, revealing regulation for quality.

According conclusion above proposed to the official to be aware on vision, missions, and objectives of department. Maximized roles human resources and formulated intuitional policy.

\section{REFERENCES}

[1] Barret, Anggelina M., Chawla, Rita. Lowe, John. Nikel, Jutta. Ukpo Eugenia. (2016). The concept of quality in education: a review of the internal literature on the concept of quality in education. EdQual working paper No. 3. EdQual RPC.

[2] Byrd, John T. \& Luthy, Michael R. (2010). "Improving Group Dynamics: Creating a Team Charter (Report)". Academy of Educational Leadership Journal 13 (14). (5483 words)

[3] Choi, Seokin. Jang Hyounseung and Hyun Joonsik. (2009). "Correlation between innovation and performance of construction firm." (Report). Canadian Journal of Civil Engineering 36, (11). 1722 (10). (5539 words).

[4] EL Sedawy, Bahgat, Ibrahim, Ahmed. (2016). "adapted model to improve e-learning system output by improving total quality management in Egypt. Egyptian computer science journal. Vol. 40 Issued on January 2016. P. 8.

[5] Fuller Jr., Jerry Bryian, Kim Hester \& Susie S. Cox. (2010). "Proactive Personality and Job Performance; Exploring Job Autonomy as a Moderator". Journal of Managerial Issues 22, (1). 17 -35 .

[6] Geyorgan, Rita. (2012). “Applying an Enhanced Technology Acceptance Model to Knowledge Management in Agricultural Extension Services. Data Science Journal, 7(1), 31-45

[7] Lonsdale, Alan. (1998). "Performance Appraisal, Performance Management and Quality in Higher Education: Contradiction, Issues, and Guiding Principles for the Future (1)." Australian Journal of Education 42.3 (Nov 1998): p.303 (1). (6922 words).

[8] Milles, M.B. \& Huberman, A.M. (1984). Qualitative Data Analysis (second Ed.). London: Sage Publication.

[9] Ministerial Regulation of National Education and Culture of Republic of Indonesia No 49 Year 2014 on the National Standard of Higher Education.

[10] Government Regulation No 19 Year 2005 on National Education Standard.

[11] Hoyle, Tena B., samek, Beverly B. \& Valois, Robert F. (2008). "Building Capacity for the Continuous Improvement of HealthPromoting Schools (General article)". Journal of School Health 78, (1), 1 - 8. (4663 words).

[12] Satori, Djam'an, \& Komariah, Aan. (2011). Metode Penelitian Kualitatif. Bandung: Alfabeta.

[13] Sergiovanni, Thomas J. et.al. (1992). Educational Governance and Administration. Boston: Allyn and Bacon.

[14] Soeprapto, Riyadi. (2010) .The Capacity Building For Local Government Toward Good Governance. World Bank.

[15] Steers, Richard M. (1991). Introduction to Organizational Behavior. New York: Harper Collins.

[16] Wefald, Andrew J. Et al. (2010). "Organisational Slack, Firm Performance, and the Role of Industry”. Journal of Managerial Issues 22 , (1) $18-70$ (18)

[17] Wei-Ping, Zhao Shuo. (2010). "Creating Active Learning Applications and Opportunities for an On-line Leadership Course". Academic of educational leadership journal 1, (3) $13-77$. 